\title{
SEED DISPERSAL, SEED ENTRAPMENT, AND SEEDLING RECRUITMENT IN A TEMPORALLY VARIABLE DESERT PLAYA
}

\author{
Amanda N. Breen ${ }^{1,2}$ and James H. Richards ${ }^{1,3}$
}

\begin{abstract}
Natural establishment of seedlings in desert playas with temporally variable precipitation hinges on many factors, including seed production, seed dispersal, seed entrapment, seed germination, and seedling survival. We investigated natural seed dispersal patterns and the effects of surface texture, wind barriers, resource availability (water and nutrients), and protection from herbivory on seedling establishment in a desert playa. We hypothesized that the seed rain would be consistent throughout the year and that seedling establishment would improve in resource-amended plots with barriers to wind dispersal. Contrary to our hypotheses, seed flux peaked seasonally during the winter, and fertilization had no consistent effect on seedling establishment. Seed availability for dispersal correlated with precipitation in the previous water year, whereas seedling recruitment was greatest when current-year precipitation during the spring germination and summer seedling growth periods was high. Gravel and barrier surface treatments contained more surviving seedlings than other surface treatments. Comparison with plots located outside of herbivore exclosures, however, showed that greater seedling presence in gravel plots may be due somewhat to protection from herbivory provided by the gravel, rather than simply to the greater seed-trapping quality of the gravel. With abundant seed availability, application of surface treatments, like coarse gravel, combined with increased seasonal water availability could lead to improved shrub establishment from seed in desert playas.
\end{abstract}

Key words: desert playa, seed rain, seedling establishment, seedling survival.

Many arid areas of the world, including much of western North America, contain dry or drying lake beds. These areas are quite barren because of high salinity levels, the presence of toxic elements (especially boron), and/or low water and nutrient availability (Dahlgren et al. 1997). Windblown soils from dry lake beds cause fine particulate dust pollution and other negative effects, including injurious humanhealth conditions (Sauder 1994). One solution to these problems is the establishment of native aridland vegetation, which can trap windblown soil (Boeken and Shachak 1994). However, natural or managed establishment of seedlings through successful seed germination and seedling survival depends on many factors: seed rain, seed entrapment, water and nutrient availability, and protection from herbivory (Harper 1977, Chambers 1995, Schupp and Fuentes 1995, Bakker et al. 1996, Nathan and MullerLandau 2000). Each factor contributing to seed germination and seedling survival becomes critical to successful plant establishment in stressful desert ecosystems. Furthermore, the temporal variability of seed production or seedling establishment depending on precipitation causes complex patterns in timing of successful natural seedling establishment and poses problems for successful restoration seeding in desert playa areas.

Two major barriers to successful seedling establishment are low seed availability and poor retention of wind-dispersed seeds (Bakker et al. 1996, Houle 1996). Under stressful environmental conditions, there can be low levels of seed production (Houle 1996, Nathan and Muller-Landau 2000, Drenovsky and Richards 2005 ) and poor entrapment. Even with sufficient seed production, entrapment in many desert locations, especially playas, may be low due to few seed-trapping obstructions and high wind speeds. In high-wind areas like desert playas, entrapment may be most important to seedling establishment.

Seed entrapment, defined as the number of seeds that remain in a microsite long enough to imbibe water, increases with increasing soil-surface particle size up to a threshold (Chambers

\footnotetext{
${ }^{1}$ Department of Land, Air, and Water Resources, University of California, Davis, One Shields Avenue, Davis, CA 95616-8627.

${ }^{2}$ Present address: WRA, Inc., 2169-G East Francisco Boulevard, San Rafael, CA 94901.

3Corresponding author. E-mail: jhrichards@ucdavis.edu
} 
et al. 1991) or with the addition of holes, depressions, or barriers to seed movement (Mott and McComb 1974, Johnson and Fryer 1992). Seed entrapment may be enhanced by increasing soil particle size to include gravel, by installing obstructions, such as fences, to trap seeds and other debris, or by creating depressions (Johnson and West 1988). Recruitment on playas may hinge on the formation of large desiccation cracks that act as barriers to seed movement (Neal and Motts 1967) and provide safe sites where a dispersed seed can remain long enough to imbibe water and germinate (Johnson and Fryer 1992).

In many areas, after seed production and retention (entrapment), successful colonization is often limited by safe-site characteristics, including water and nutrient availability as well as herbivory (Urbanska 1997, Fort and Richards 1998). The limited availability of water and nutrients in deserts inhibits rapid seedling growth and eventual survival (Mott and McComb 1975, Mun and Whitford 1989). Nutrient and water availability affect most stages of seedling establishment but are particularly important for early seedling growth and survival (Harper 1977). Years with high precipitation cause nutrient pulses that allow plants to produce more seed for the next year, but these pulses have a more immediate benefit to seedlings that must overcome stresses present during seed germination and early seedling growth (James et al. 2006, Breen and Richards 2008a).

Lastly, after seed entrapment and resource availability, herbivory, primarily by jackrabbits and small rodents, appears to be an important determinant of successful seedling recruitment in desert playas (Harper 1977, Baskin and Baskin 1988). In good rainfall years with abundant seed germination, herbivory damage to seedlings may decrease due to satiation of herbivores by abundant vegetation. Likewise, in years of limited or no precipitation, damage to seedlings from herbivory may increase, thereby decreasing successful seedling recruitment, despite potentially good seed production and retention in the area (A.N. Breen personal observation).

In this study, we measured seed flux on the Owens Lake playa, California, at the MojaveGreat Basin desert ecotone to explore rates and potential inhibitors of seed dispersal and seedling establishment. Improved understanding of seed production, seed dispersal, and seedling establishment on the Owens Lake playa is needed to increase seedling recruitment and to stabilize soil for dust mitigation, which depends on establishment of native vegetation (de Soyza et al. 2000). These results will aid managers in determining best approaches to increase seedling growth and survival, not only at the saline, sandy Owens Lake playa, but also at similar arid sites worldwide. The results are also important to understanding spatial and temporal variation in natural seedling establishment in deserts.

Density of seed rain can vary between locations and years, since production of seed depends on precipitation, with only a few species providing substantial contributions (Urbanska and Fattorini 2000); but it is unknown how much, at what rate, or during which months seed moves across sections of the Owens Lake playa. Seedling establishment has occurred in the past on Owens Lake shorelines exposed since the 1920s, as demonstrated by the presence of vegetation on those features. However, current establishment is extremely limited. We hypothesized that (1) precipitation affects the amount and diversity of seed available (i.e., seed production) for entrapment within the Owens Lake playa, that (2) increased distance from established, seed-producing plants results in lower seed availability and lower diversity of seed present, that (3) increased soil surface barriers to seed dispersal increase entrapment of seed within the Owens Lake playa, that (4) nutrient and water enrichment contributes to greater seed germination and seedling establishment at Owens Lake playa, and that (5) partial protection from herbivore damage to seedlings results in greater seedling survival and establishment. By understanding some of the factors that control seed production, seed entrapment, and early seedling establishment and survival, restoration projects in arid desert environments, such as the Owens Lake playa, can increase seedling recruitment and extend the longevity and success of such projects.

\section{Methods}

Study Sites

Owens Lake, California, is located on the eastern side of the southern Sierra Nevada, in the Owens Valley between the Sierra Nevada and the Inyo-White Mountains $\left(30^{\circ} \mathrm{N}, 118^{\circ} \mathrm{W}\right.$; 
$1083 \mathrm{~m}$ elevation). Diversion of water from the Owens River began in the early part of the 20th century and has resulted in a dry lake bed (playa) of approximately $285 \mathrm{~km}^{2}$ (Sauder 1994). The generation of fine particulate dust from the playa has created a severe air pollution problem in the area that must be reduced or eliminated for both health and aesthetic reasons. One solution used to mitigate the dust problem is the establishment of native, salttolerant Mojave and Great Basin desert plant species to cover and stabilize the soil.

The Owens Lake playa environment is severe and arid (average $\mathrm{ET}_{0}=1580 \mathrm{~mm} \cdot \mathrm{y}^{-1}$, average precipitation $=137 \mathrm{~mm} \cdot \mathrm{y}^{-1}$ with over $80 \%$ occurring as rain between October and April), with high average wind speeds and extreme temperature variation (mean maximum July temperature $=37.2{ }^{\circ} \mathrm{C}$, mean minimum January temperature $=-3.0{ }^{\circ} \mathrm{C}$; Sauder 1994, Ono et al. 2000, Dickey et al. 2005). Precipitation was highly variable during the study, with 122,38 , and $254 \mathrm{~mm}$ of precipitation for the 2001, 2002, and 2003 water years, respectively (a water year, from 1 October to 30 September, represents autumn and winter precipitation that accumulates in the soil and can be used during the growing season). Playa soils (Entisols) are extremely alkaline ( $\mathrm{pH}$ 10) and very saline and have high boron concentrations. The rooting depth of vegetation is restricted by shallow, saline, anoxic groundwater (Dahlgren et al. 1997, Dickey et al. 2005).

Two readily accessible, representative sites on the playa were used. The Lake Minerals Road (LMR) site was located on a 1920s shoreline of the lake. Coarse sand and gravel soils at this site were described by Dahlgren et al. (1997). Currently seedling establishment is low at this site but has occurred in the past, based on the presence of large and small plants of several native species (Table 1). Herbaceous cover was approximately $10 \%$, with dominant vegetation including Atriplex parryi (Parry's saltbush), Atriplex confertifolia (shadscale), Sarcobatus vermiculatus (greasewood), Suaeda moquinii (bush seepweed), Distichlis spicata (saltgrass), Schismus arabicus (Mediterranean grass), and Cleomella obtusifolia (Mojave stinkweed).

The vegetation-on-sand (VOS) site was located on the playa and was barren, with a sandy, salt-crusted soil ( $87 \%$ sand, $7 \%$ clay). Prior to drip irrigation and the establishment of transplanted plants for a separate study, seedling establishment was not occurring at this location. Atriplex parryi, Sarcobatus vermiculatus, Suaeda moquinii, and Distichlis spicata were planted in the summer of 2001 for separate studies at the VOS site. These plants began to produce and disperse seeds onto the playa during the 2002-2003 winter season, affecting seed rain and seedling establishment at this site beginning with the 2003 field season. At both sites, in addition to Distichlis spicata, the species of major interest for dust mitigation were Atriplex parryi, Sarcobatus vermiculatus, and Suaeda moquinii.

\section{Field Methods}

We collected seed directly from all species that were potential seed sources in the area in 2001-2003 and developed a seed key and library. To determine seed rain at the 2 study sites, we set up seed-trap devices, each consisting of a 3.5-L plastic pot within another identical pot (17 cm deep, 16-cm-diameter opening). The outer pot allowed removal of the inner trap pots without disturbance of the surrounding soil. The inner pot was filled to $4 \mathrm{~cm}$ deep with 2-cm-diameter gravel. The gravel trapped seeds, allowed them to remain dry, and prevented granivory (Fort and Richards 1998). Polyester batting plugs in the bottom of the pots enhanced drainage and prevented seed losses. After seed traps (30 at the LMR site and 32 at the VOS site) were installed on 14 October 2001, they were collected seasonally for 2 years on the following dates: 9 February, 1 May, 18 July, and 11 December 2002; and 12 March, 2 July, and 21 August 2003. We used sieves (10 $\mathrm{mm}$ and $2 \mathrm{~mm}$ ) to separate gravel, seed, other litter, and sand. Seeds were separated, identified with the seed key and library, and counted using a dissecting microscope. Counts of trapped seeds were standardized by dividing the total number of seeds trapped by the number of days in the collection period, multiplying by 30 (for an approximate monthly total), and then dividing by the area sampled by the trap openings. For overall totals, the averages of all traps per site were used; but for statistical analyses, individual seed trap values were used.

Surface treatments were designed to eliminate factors that limit seed entrapment and seedling recruitment. In early autumn 2001, at both study sites, we set up replicate blocks, each with four $30 \times 30$-cm treatment plots: unirrigated (native), irrigated (control), coarse 
gravel, and a 7-cm-high, T-shaped wood barrier $(\operatorname{wood} T)$. Because this experiment was focused on identifying factors that might enhance seed trapping and retention as well as seedling growth and survival (seedling recruitment), all treatments, except unirrigated, were surface drip irrigated with pressure-compensating emitters (2 L per hour for 1 hour per day) from late February to August each year to maintain moist soil for enhanced germination. Half of the replicate blocks received NPK fertilizer (10.5 g slow-release $\mathrm{KNO}_{3}$ and $2 \mathrm{~g}$ triplesuper-phosphate) with complete micronutrients (1.3 g Apex Emerald, Simplot, Lathrop, CA), spread evenly over the surface of each $30 \times 30$ $\mathrm{cm}$ plot each year. The irrigated (control) treatment, which was lightly raked at the start of the experiment, provided control for germination of seed from the existing soil seed bank and was also compared to the unirrigated (native) treatment to assess precipitation limitations to seed germination and seedling establishment. The coarse gravel treatment consisted of a shallow layer of sieved, cleaned 2-cm gravel and was drip irrigated. The wood $\mathrm{T}$ treatment utilized two $30 \times 8$-cm pieces of wood joined with screws in a T shape. The wood T's were placed on the ground so they projected approximately $7 \mathrm{~cm}$ above the soil surface, which was drip irrigated. The amount of seed, litter, and debris were quantified in 3 locations around each T (2 "sides" and a "top"), and we determined that the amount trapped was equivalent among all 3 locations around the $T$. The total of all 3 locations at each wood $T$ was used for each plot.

In arid ecosystems, seedling abundance of desert species is almost never high in 2 successive seasons (Chambers 1995, Guo and Brown 1997, Whitford et al. 1999). For this reason, the experiment was conducted for 2 years. Surface treatments were observed and surviving seedlings counted on 2 May, 12 June, 1 July, 18 July, and 3 August 2002 and on 12 March, 27 March, 18 April, 22 May, 2 July, and 21 August 2003. Surviving seedlings were marked with colored toothpicks at each survey date. Sampling times differed between years due to precipitation differences between years and subsequent differences in germination timing. At the LMR site, there were 30 replicate blocks each with all 4 surface treatments ( 15 blocks spaced along a 60-m-long east-west transect and 15 spaced along a similar north-south transect). At the VOS site, there were 32 blocks (16 spaced along a 180-m-long north-south transect and 16 spaced along a 240-m-long east-west transect; groups of 4 blocks were located within $5 \mathrm{~m}$ of plots of the shrubs and saltgrass planted for a separate study at that site). Within blocks, treatments were located $0.25 \mathrm{~m}$ away from each other, and locations were randomly assigned (see statistical analyses). To standardize data, we divided the total number of emerged seedlings by area (area of one plot multiplied by the total number of plots, for totals, or area of one plot, for individual data used in statistical analyses). We determined seedling survival by following marked seedlings throughout each growing season.

To eliminate any possible effects of herbivory on emergence, growth, and survival of surface-treatment seedlings, a jackrabbitexclusion fence surrounded both the LMR and the VOS sites. Additional plots with the gravel treatment were placed both inside and outside of the fence at the LMR site, where many jackrabbits were observed, to determine the effect of grazing by herbivores. We added 10 viable seeds each of Atriplex parryi and Sarcobatus vermiculatus that had been prescarified to enhance germination in these plots. Because viable seeds of these species germinate rapidly, 10 seeds allowed us to measure seedling growth and survival at each site visit. These measurements allowed us to compare herbivory effects quantitatively at the LMR site.

In addition to the surface treatment experiment and the additional herbivory effect plots, we marked a separate cohort of naturally established seedlings of Atriplex parryi, Sarcobatus vermiculatus, and Suaeda moquinii at the VOS site $(n=300$ seedlings per species) and followed their growth and survival over one season (March-August 2003).

\section{Statistical Analyses}

All studies were set up as randomized complete-block designs, and sites were analyzed separately. Observations were weighted by the inverse of the variance within each treatment to correct for heterogeneity of variance. Observations were then analyzed using repeated-measures ANOVA, with sampling period as the within-subject effect (Neter et al. 1996, Stanton and Thiede 2005). Factors for the surface-treatment experiment were block, surface treatment, and fertilizer. All interactions were included in this model, and block was treated as random. 
TABLE 1. Major seed-producing plant species near the Lake Minerals Road (LMR) study area. There was a similar species composition approximately $2 \mathrm{~km}$ from the vegetation-on-sand (VOS) site. The Owens Lake is at the boundary between the Great Basin Desert (a cold desert) and the Northern Mojave Desert (a warm desert). Wetland species occurred in the remnant Owens River Delta. Seeds of the species listed were collected from adult plants at some point in 2001-2003 but not necessarily in all years, as precipitation varied greatly between years. Seeds of all these species were in the seed key and library. This species list is not comprehensive, as more than 359 species have been identified in the Owens Lake area ( Jim Paulus personal communication); however, it contains the major species present near the sites.

Species

Anemopsis californica (Nutt.) Hook. \& Arn.

Artemisia tridentata Nutt.

Atriplex canescens (Pursh) Nutt.

* Atriplex confertifolia (Torrey \& Frémont) S. Watson

* Atriplex hymenelytra (Torrey) S. Watson

* Atriplex lentiformis (Torrey) S. Watson

* Atriplex parryi S. Watson

Atriplex phyllostegia (Torrey) S. Watson

Atriplex polycarpa (Torrey) S. Watson

* Bassia hyssopifolia (Pallas) Kuntze

Berula erecta (Hudson) Cov.

Camissonia claviformis (Torrey \& Frémont) Raven

Carex davyi Mackenzie

Carex douglasii Boott

Cercocarpus betuloides Torrey \& A. Gray

* Chrysothamnus nauseosus (Palla.) Britton

* Cleomella obtusifolia Torrey \& Frémont

Cordylanthus ramosus Benth.

* Distichlis spicata (L.) E. Greene

Eriastrum pluriflorum (A.A. Heller) H. Mason

** Eriogonum ampullaceum J. Howell

** Eriogonum brachyanthum Cov.

** Eriogonum brachypodum Torrey \& A. Gray

** Eriogonum inflatum Torrey \& Frémont Eriophyllum wallacei (A. Gray) A. Gray Gilia latifolia S. Watson

Gilia leptomeria A. Gray

Gilia stellata A.A. Heller

Helianthus annuus $\mathrm{L}$.

Heliotropium curassavicum $\mathrm{L}$.

Hemizonia kelloggii E. Greene

Hymenoclea salsola A. Gray

* Hypochaeris glabra L.

* Lepidium flavum Torrey

* Lepidium perfoliatum $\mathrm{L}$.

Linanthus dichotomus Benth.

Malacothrix glabrata A. Gray

Mimulus guttatus DC.

Monoptilon bellioides (A. Gray) H.M. Hal

Muhlenbergia filiformis (Thurber) Rydb.

Nitrophila occidentalis (Nutt.) Moq.

Petalonyx thurberi A. Gray

Phacelia fremontii Torrey

Plagiobothrys kingii (S. Watson) A. Gray

* Polypogon monspeliensis (L.) Desf.

Psathyrotes annua (Nutt.) A. Gray

* Psathyrotes ramosissima (Torrey) A. Gray

Psorothamnus arborescens var. arborescens (A. Gray) Barneby
TABLE 1. Continued.

\begin{tabular}{l}
\hline Species \\
\hline Rorippa sinuata (Torrey \& A. Gray) A. Hitchc. \\
Salsola tragus L. \\
* Sarcobatus vermiculatus (Hook.) Torrey \\
* Schismus arabicus Nees \\
Scirpus pungens Vahl \\
* Suaeda moquinii (Torrey) E. Greene \\
Tamarix ramosissima Ledeb. \\
*** Typha domingensis Pers. \\
*** Typha latifolia L. \\
* Unknown seed species (several different species) \\
\hline * Found in seed traps. \\
** Erigonum spp. were indistinguishable from each other. \\
*** Typha spp. were indistinguishable from each other.
\end{tabular}

We tested the assumption of homoscedasticity and used the Greenhouse-Geisser test to adjust probabilities for unequal correlations among pairs of repeated measures, when the assumption for sphericity was rejected $(P<0.05)$. In addition, we used polynomial contrasts to partition interactions between treatments and to test the following a priori hypotheses: (1) Does irrigation affect seedling establishment regardless of surface texture? (2) Does rougher surface texture (gravel or wood T) increase seedling establishment over the irrigated treatment (the control). Post-hoc mean separation was performed using the Ryan-Einot-Gabriel-Welsch multiple range test (SAS Institute, Inc. 2001). Least-squares analysis was used for correlations of seed trap data to surface-treatment seedlingpresence data.

We analyzed the diversity of seed species in the traps using the Shannon diversity index (number of abundant [i.e., $\geq 5 \%$ of sample] species in the sample), which was calculated using the following formula:

$$
\text { Diversity } H^{\prime}=\sum p \ln p \text {, }
$$

where $p$ was the proportion of seeds of each species divided by the total number of seeds of all species in the sample (Kent and Coker 1992, McCune and Grace 2002).

\section{Results}

\section{Seed Trapping}

Traps captured seed from many species at both study sites (Table 1). Not all adult plant species present in the surrounding area were represented in the collected seed rain. Unrepresented species included those that produce 
LMR site
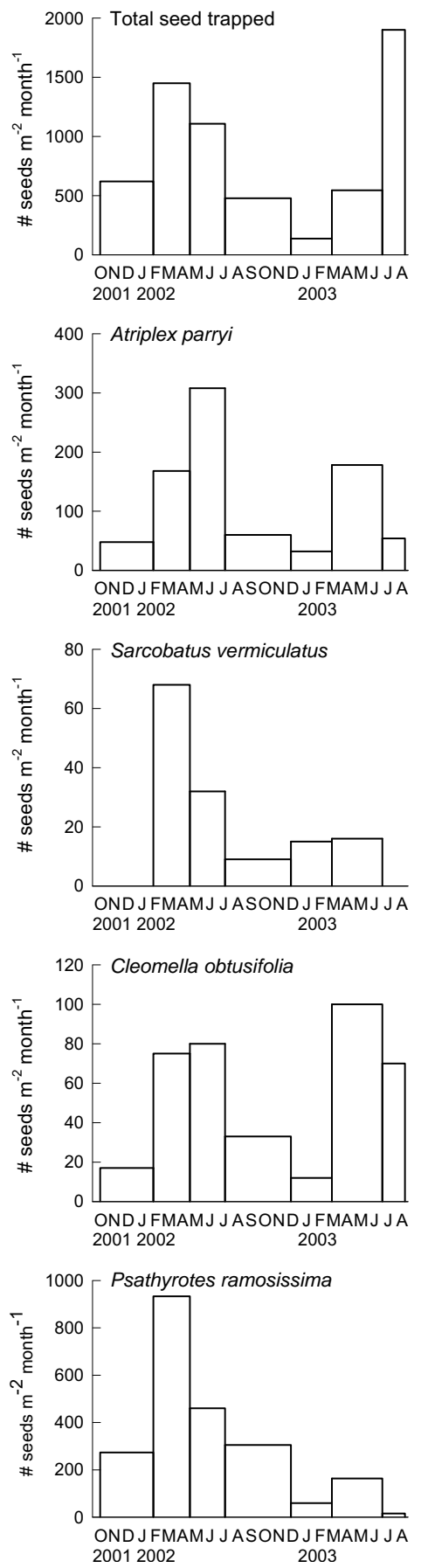

Fig. 1. Total number of seeds collected during 7 seed trap collection periods at the LMR site. These totals are for 30 seed traps. The $\mathrm{x}$-axis in each panel represents time, with months abbreviated by first letter, starting in October 2001 and ending in August 2003. Note differences in the $y$-axis scale among panels.
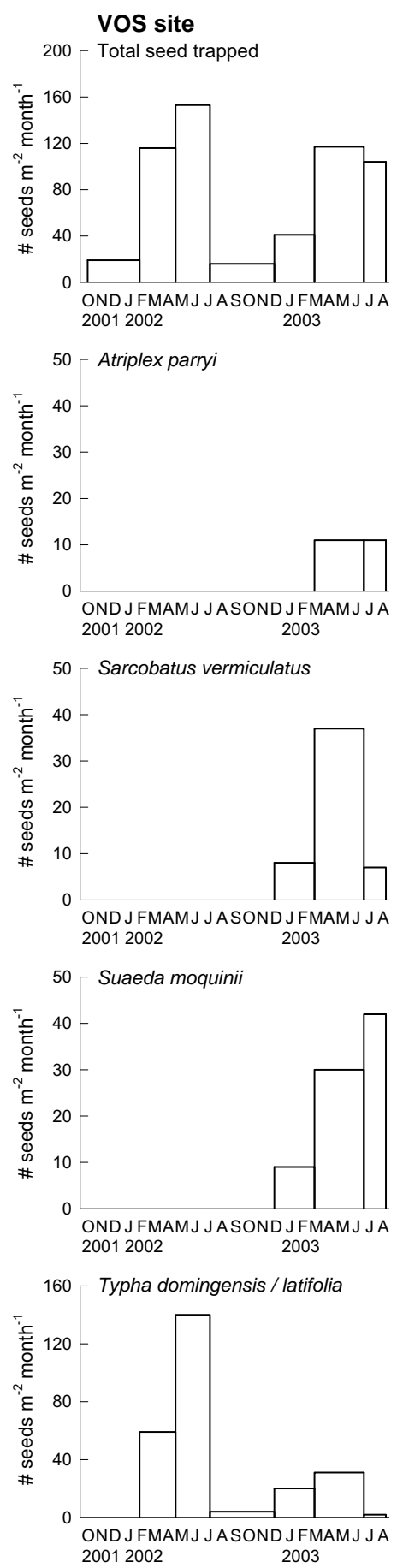

Fig. 2. Total number of seeds collected during 7 seed trap collection periods at the VOS site. These totals are for 32 seed traps. The $\mathrm{x}$-axis in each panel represents time, with months abbreviated by first letter, starting in October 2001 and ending in August 2003. Note differences in the y-axis scale among panels. 


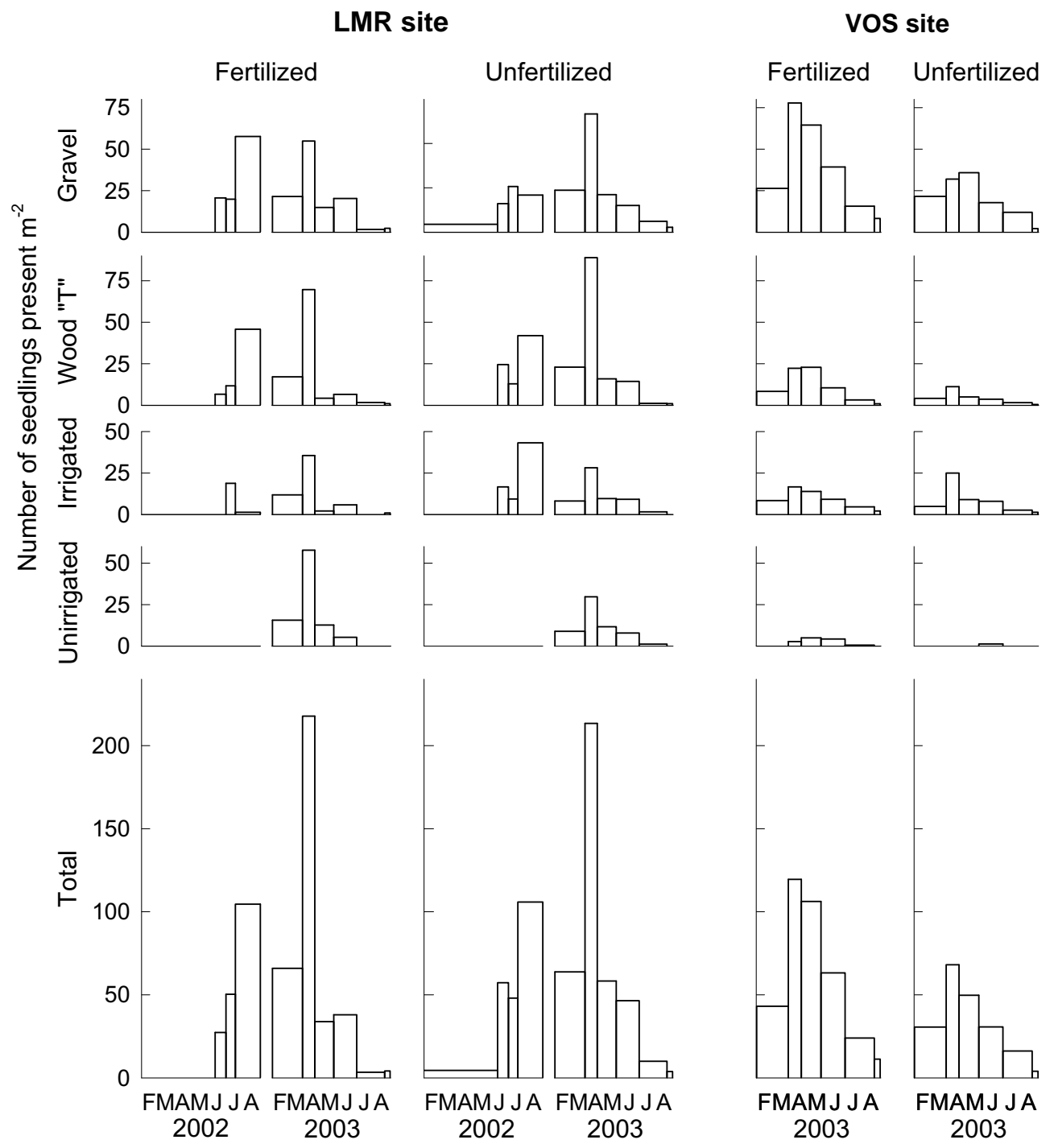

Fig. 3. Number of seedlings germinating and surviving in the surface treatment experiments at the LMR and VOS sites, for fertilized and unfertilized plots. Breaks in the $\mathrm{x}$-axes are for fall and winter months when no seedling emergence occurred. Each seedling emergence period was from 1 February to 31 August (see methods for dates) for each study year $(n=15-16$ plots per treatment per site). No data are shown for the VOS site for 2002 because no seedlings were present in any of the treatments.

seeds smaller than the sieve threshold. Species with the greatest number of trapped seeds generally were Psathyrotes ramosissima, Eriogonum spp., Schismus arabicus, Cleomella obtusifolia, and Atriplex parryi for the LMR site and seeds of Typha spp. plus the native shrubs for the VOS site (Table 1, Figs. 1, 2). An exception to this pattern was the very high number of seeds of Distichlis spicata, a perennial grass, which contributed to the high number of total seeds trapped during the summer 2003 period at LMR. At the LMR site, timing of seed dispersal was similar for all main species. The seed rain varied by year, with more seeds present for all species during the 2001-2002 study period, except for Cleomella obtusifolia at the LMR site and the planted, irrigated, fertilized shrub species at the VOS site (Figs. 1, 2). At the LMR site, there was no correlation between number of trapped seeds 
TABLE 2. Total monthly precipitation $(\mathrm{mm})$ at Owens Lake for 2000-2003. Data were obtained from the California Irrigation Management Information System (CIMIS; www.cimis. water.ca.gov) and the Western Regional Climate Center (WRCC; www.wrcc.dri.edu). To provide representative precipitation for both study sites, monthly precipitation was averaged for 4 sites in 2003: North Owens Lake (CIMIS), South Owens Lake (CIMIS); Independence (WRCC) and Haiwee (WRCC). Because data were not available at the North and South Owens Lake stations prior to 2003, we used an average of the Independence and Haiwee station data for 2000-2002. The average of these stations correlated well with the average of the Owens Lake stations in 2003 (January-June, August-December; $r^{2}=$ $0.95, n=11$ ). Precipitation values of more than $5.0 \mathrm{~mm}$ are in bold.

\begin{tabular}{lcccr}
\hline Month & 2000 & 2001 & 2002 & 2003 \\
\hline January & $\mathbf{1 0 . 5}$ & 37.5 & 0.1 & 0.4 \\
February & $\mathbf{3 4 . 7}$ & $\mathbf{4 2 . 3}$ & 0 & $\mathbf{4 3 . 5}$ \\
March & $\mathbf{2 3 . 4}$ & $\mathbf{1 7 . 9}$ & 1.0 & $\mathbf{5 . 9}$ \\
April & 2.5 & 2.2 & 2.5 & 3.6 \\
May & 3.2 & $\mathbf{7 . 0}$ & 1.0 & 4.8 \\
June & 0.1 & 0 & 0 & 0.1 \\
July & 0 & $\mathbf{1 2 . 2}$ & 0.3 & $\mathbf{2 0 . 6}$ \\
August & 3.4 & 0 & 0 & $\mathbf{2 2 . 3}$ \\
September & 0 & 0 & 0.1 & $\mathbf{5 . 7}$ \\
October & 3.0 & 0 & 0 & 0.6 \\
November & 0 & $\mathbf{2 4 . 8}$ & $\mathbf{1 0 7 . 8}$ & $\mathbf{1 2 . 8}$ \\
December & 0 & $\mathbf{8 . 0}$ & 39.2 & 4.1 \\
\hline
\end{tabular}

and number of seedlings germinating in surface treatments located next to seed traps (see Emergence in Surface Treatments, below).

At the VOS site, shrubs of Atriplex parryi, Sarcobatus vermiculatus, and Suaeda moquinii planted for another study in the 2001 growing season began to produce seed late in 2002. Seed from these planted, irrigated, fertilized shrubs dramatically increased and dominated the seed rain at the VOS site during the winter and spring of 2002-2003 (Fig. 2). Consequently, there was a positive correlation between the number of seeds trapped and the number of seedlings emerging at the VOS site. Typha spp. contributed the only significant seed rain at VOS during the first year of study (2001-2002) because of the great distance between this site and any other vegetation that could produce seeds. Seeds of Typha spp. disperse great distances, and the amount trapped was greatest during the spring collection periods in 2002 (Fig. 2). Atriplex parryi seed dispersal was significantly different temporally from either Sarcobatus vermiculatus $(P=0.05)$ or Suaeda moquinii $(P=0.03)$.

Seed-rain species diversity varied among the 2001-2003 seed-trap collection periods $(P<$ 0.0001). The Shannon diversity index for seed species at the LMR site was greatest for the May 2002 collection period during the 2001-2002 dispersal season and for the December 2002 through March 2003 collection periods during the 2002-2003 dispersal season (maximum = 3.5 , average $=2.9$ ).

\section{Emergence in Surface Treatments}

Seedling establishment occurred naturally (i.e., in unirrigated treatment plots) at both sites (Fig. 3). At the VOS site, there was no seedling establishment in plots of any treatment in 2002 , but the planting and growth of seed-producing shrubs there significantly increased seed presence and seedling establishment in 2003. Seedling emergence was positively correlated to seed rain at the VOS site. At the LMR site, fertilizer increased the number of seedlings in some plots, but this increase was not significant overall $(P=0.71$, Fig. 3). Total seedling establishment at the LMR site was greatest in the 3 irrigated treatments during the summer months of the 2002 growth season and in all treatments during the spring months of the 2003 growth season (Fig. 3). The gravel and the wood T treatments had the greatest number of germinated seedlings at the LMR site (Fig. 3). Gravel treatments had more seedlings present than any other treatment $(P=0.003)$, and irrigated treatments had more seedlings present than unirrigated treatments $(P=0.0002)$, indicating that water played a role in promoting seedling emergence at the LMR site. The unirrigated plots without fertilizer had the lowest number of established seedlings at the LMR site, especially during 2001-2002, when precipitation was very low (Table 2).

At both sites, seedling presence in plots located outside of the jackrabbit exclosure was significantly lower than seedling presence in plots protected from herbivory $(P=0.05)$. In the unprotected gravel treatments, seedlings were cut by herbivores (jackrabbits or small rodents) at gravel level, allowing them to survive; but in the wood $\mathrm{T}$, irrigated, and unirrigated plots, seedlings were cut to soil level, which led to greater seedling mortality.

In contrast to the LMR site results, fertilizer additions at the VOS site significantly increased the number of surviving seedlings $(P=0.05)$. At the VOS site, the gravel surface treatment had the greatest total number of seedlings present $(P=0.01$; Fig. 3). Irrigated (control) treatments were not significantly greater than 
unirrigated treatments at the VOS site, so irrigation did not increase seedling establishment at this site during the wet summer of 2003. The lowest number of seedlings present at the VOS site occurred in unirrigated surface plots without fertilizer. Seedling emergence differed by species, with fewer Atriplex parryi or Sarcobatus vermiculatus seedlings emerging than Suaeda moquinii $(P=0.008)$ seedlings. Survival at the VOS site to the end of the 2003 study season in unirrigated plots was similar for the 3 shrub species (50\% average).

Diversity of surviving seedlings varied significantly over time at the LMR site, with minimum Shannon diversity indices during the 2001-2002 growth season and maximums in both fertilized and unfertilized plots during the 27 March 2003 sampling (data not shown). In nearly every sampling period, unfertilized plots had greater Shannon diversity indices for seedlings than fertilized plots, but this difference was not significant $(P=0.3)$.

\section{DisCUSSION}

Desert ecosystems generally do not have high plant cover, and the diversity of species may be low partly because of abiotic constraints to seedling establishment (Barbour et al. 1993). Our study area at Owens Lake, California, has established vegetation on old lake shorelines, but current seedling establishment is low. One factor contributing to the low percentage of vegetation cover and low diversity of species at this site is a lack of seed due to the distance to established vegetation or the low seed production by that vegetation. Resource-limited plants produce few seeds, particularly in drought years (Drenovsky and Richards 2005, Breen and Richards 2008a, 2008b). Other studies at playa sites have found that seed entrapment rates can be high but depend on texture features present on the playa surface, such as cracks, stones, or indentations (Johnson and Fryer 1992, Fort and Richards 1998, Mandak and Pysek 2001) or on seed morphology (Chambers 2000). In this study, seeds from at least 19 species dispersed onto the LMR site throughout the growing season at rates adequate for seedling establishment. However, at the VOS site, which was far from established vegetation, seeds of most species were not present until planted shrubs and grasses from another study began to produce seed locally. These results suggest that at the very large $\left(285-\mathrm{km}^{2}\right)$ Owens Lake playa, large distances from seed-producing plants limit the amount and diversity of seed rain.

Quantity and diversity of captured seed differed between years at the LMR site (similar to Gage and Cooper 2005), most likely due to the great seasonal and annual differences in precipitation during the study (Table 2). Seed captured in the first year of study was produced by shrubs using precipitation from the 2001 water year (1 October 2000-30 September 2001). During the 2001 water year, precipitation was $122.1 \mathrm{~mm}$, with $80 \%$ occurring during the winter months of January, February, and March, providing a soil-moisture resource for shrub growth. In contrast, during the 2002 water year (1 October 2001-30 September 2002), precipitation was $37.8 \mathrm{~mm}$, with only $2.9 \%$ occurring in January, February, or March 2002; and soil moisture was extremely low for shrub growth. Thus seed production was low in 2002 , in contrast to 2001 , because it followed an exceptionally dry winter (Table 2). In years with low precipitation, fewer seeds are produced by established plants (Mott and McComb 1975, Harper 1977, Humphrey and Schupp 1999), although this effect may be delayed and also depends on seasonality of the precipitation (Drenovsky and Richards 2005, Richardson et al. 2005).

A second possible explanation for low vegetation cover and diversity at Owens Lake is lack of seedling establishment. Lack of seedling establishment may be due to lack of seed entrapment or lack of enough safe sites that have adequate resources to support establishing seedlings and/or are protected from herbivory. However, we found that seed entrapment did occur, as seedling establishment was successful at the VOS site after seed availability was increased in the area (Fig. 3), and that survival was possible for germinated seedlings of perennial shrubs without irrigation (2003 VOS survival data not shown). In addition, we found that surface treatments increased seedling emergence but that some seedling establishment occurred in all treatments (Fig. 3). This finding supports the hypothesis that seedling recruitment can be improved by increasing surface roughness with larger particle size or with obstructions to seed movement (increased seed entrapment) and/or by increasing resource availability with water, and possibly nutrient, additions. 
Precipitation amount and seasonality also affect seed germination and seedling survival but with different temporal responses than for seed production (Harper 1977, Weiner et al. 1997). Seedling emergence and establishment (i.e., survival) did not occur in unirrigated plots in 2002 but did occur in unirrigated plots in 2003 at both sites (Fig. 3). This large difference between years can be attributed to differences in precipitation, especially precipitation falling during the spring germination and summer seedling-growth periods. In contrast to the 2002 water year precipitation $(37.8 \mathrm{~mm})$, the 2003 water year precipitation was $253.9 \mathrm{~mm}$. Also, in the 2002 water year, only $12.7 \%$ of the very low annual amount fell from February to Augustthe months that are critical for germination and seedling establishment and survival at Owens Lake (Table 2). In contrast, in the 2003 water year, $41.9 \%$ of the high annual precipitation fell in that period. Manning (2003) found similar seasonal precipitation patterns throughout the Owens Valley in these years. Seedling emergence and survival were high when precipitation was high from late winter and through summer, as in 2003. Seedling emergence and survival were low when precipitation during this period was low, as in 2002 (Table 2, Fig. 3). Similar to other studies, yearly variation in precipitation, temperature, and other climatic variables can adversely affect seed germination and establishment (Wood and Morris 1990, Harris and Facelli 2003).

As precipitation increases (or with irrigation in restoration situations), nutrient availability and herbivory protection become important limiting factors for desert plant community and ecosystem dynamics (Baskin and Baskin 1998, Burke et al. 1998, Garcia-Fayos et al. 2000). Nutrient pulses, coincident with higher water availability, allow seedlings to overcome stresses present during germination and early seedling growth—critical life history stages that are often subject to high mortality rates (McLendon and Redente 1991, Ungar 1996, Miao et al. 1997). Periods of favorable conditions for seedling establishment may occur intermittently or not at all for many years (Wertis and Ungar 1986). In this study, the addition of nutrients did not significantly increase the number of surviving seedlings present at the LMR site. However, at the VOS site, nutrient addition did increase seedling establishment. This apparent contradiction is hypothesized to result from very low nutrient stores in soils at the VOS site, which was previously unvegetated, and the somewhat higher nutrient stores in the soil at the LMR site (although this site still has low nutrient availability compared to most other vegetation types; see Breen and Richards 2008a), which currently has established vegetation (nutrient data not shown).

Lastly, after seed entrapment and resource availability, herbivory appears to be an important determinant of successful seedling recruitment. In favorable years, herbivory damage to seedlings appears to decrease because of herbivore satiation by the large number and rapid growth of emergent seedlings. During the first season of this study, when precipitation was extremely limited, all seedlings in the plots exhibited signs of herbivore (probably jackrabbit) damage. We also found that herbivory interacts significantly with the role that surface texture plays in successful seedling establishment. Because of the size of the gravel (up to $2 \mathrm{~cm}$ ), the gravel surface treatment protected small, young seedlings from browsing by jackrabbits. However, during the 2002-2003 field season, precipitation was high and seed germination, especially of annuals, was very high, apparently satiating local jackrabbit populations and eliminating herbivory as a cause of seedling mortality in our experiments. Thus, the effects of herbivory are expected to increase in years when precipitation, germination, and plant growth are limited (Kuijper et al. 2004), although populations of herbivores are also expected to fluctuate temporally.

Data on the seed rain and seedling establishment at Owens Lake provided both expected and unexpected results. These results support the broad conclusion that seedling establishment at Owens Lake playa is possible but depends on many factors, including seed production of established vegetation, distance from seed-producing plants, seed entrapment, availability of safe sites for growth and survival of seedlings (including resource availability and protection from herbivory), and perhaps a cascade of additional, yet-unknown factors (Aguilera and Lauenroth 1993, Humphrey and Schupp 1999, Shumway 2000, Facelli and Temby 2002). Our results indicate that seed availability could be a limiting factor to seedling establishment in areas of the Owens Lake playa far from established vegetation (such as the VOS site). Similar patterns would be 
expected in most large desert playas. However, the results also show that seed availability can be increased in a relatively short time by addition of drip-irrigated and fertilized shrubs (within 1.5 years of planting, in this study at the VOS site). Other studies have shown how seed production can be increased by fertilizing established, native shrubs (Drenovsky and Richards 2005, Breen and Richards 2008b). Unexpectedly, fertilizer treatments did not result in significantly more seedlings at the LMR site, but did at the VOS site. Seed entrapment did occur on all surface treatments but could be improved with strips or patches of gravel or other obstructions to seed movement. Seedling survival was relatively high (50\%) without irrigation on the dry lake bed through the summer of 2003 on soils where salinity had been reduced by leaching in the previous year. Seedling survival without irrigation only occurred, however, after a good winter-spring precipitation period and with an unusually high amount $(44.9 \mathrm{~mm})$ of precipitation in July and August (Table 2) In areas near established vegetation (such as the LMR site), seed availability and seed entrapment alone do not appear to be limiting seedling establishment at Owens Lake. Rather, interactions of precipitation amount and seasonality, safe-site availability, soil nutrient availability, and herbivory appear to determine seedling establishment. In deserts, especially on open playa surfaces, successful seedling establishment will vary spatially and temporally as seed production, seed entrapment, resource availability, and herbivory, among other factors, vary.

\section{ACKNOWLEDGMENTS}

Funding was provided by an NSF Graduate Research Fellowship (ANB) and the California State Lands Commission (C-99017). We also thank the California Agricultural Experiment Station, the Los Angeles Department of Water and Power, and U.S. Borax (Lake Minerals Operations). We acknowledge research assistance provided by members of the Richards lab.

\section{Literature Cited}

Aguilera, M.O., and W.K. Lauenroth. 1993. Seedling establishment in adult neighborhoods intraspecific constraints in the regeneration of the bunch- grass Bouteloua gracilis. Journal of Ecology 81:253-261.

Bakker, J.P., P. Poschlod., R.J. Strykstra, R.M. Bekker, and K. Thompson. 1996. Seed banks and seed dispersal: important topics in restoration ecology. Acta Botanica Neerlandica 4:461-490.

Barbour, M., B. Pavlik, F. Drysdale, and S. Lindstrom. 1993. California's changing landscapes. California Native Plant Society, Sacramento, CA.

BASKIN, C.C., AND J.M. BASKIN. 1998. Seeds: ecology, biogeography, and evolution of dormancy and germination. Academic Press, San Diego, CA.

Boeken, B., AND M. Shachak. 1994. Desert plant communities in human-made patches: implications for management. Ecological Applications 4:702-716.

Breen, A.N., AND J.H. Richards. 2008a. Seedling growth and nutrient content of two desert shrubs growing in amended soil. Arid Land Research and Management 22:46-61.

2008b. Irrigation and fertilization effects on seed number, size, germination and seedling growth: implications for desert shrub establishment. Oecologia 157:13-19.

Burke, I.C., W.K. Lauenroth, M.A. Vinton, P.B. Hook, R.H. Kelly, H.E. Epstein, M.R. Aguiar, M.D. Robles, M.O. Aguilera, K.L. Murphy, and R.A. Gill. 1998. Plant-soil interactions in temperate grasslands. Biogeochemistry 42:121-143.

Chambers, J.C. 1995. Disturbance, life-history strategies, and seed fates in alpine herbfield communities. American Journal of Botany 82:421-433.

2000. Seed movements and seedling fates in disturbed sagebrush steppe ecosystems: implications for restoration. Ecological Applications 10:1400-1413.

Chambers, J.C., J.A. MacMahon, and J.H. Haefner. 1991. Seed entrapment in alpine ecosystems: effects of soil particle size and diaspore morphology. Ecology 72:1668-1677.

Dahlgren, R.A., J.H. Richards, And Z. Yu. 1997. Soil and groundwater chemistry and vegetation distribution in a desert playa, Owens Lake, California. Arid Soil Research and Rehabilitation 11:221-244.

De Soyza, A.G., J.W. Van Zee, W.G. Whitford, A. Neale, N. Tallent-Hallsel, J.E. Herrick, and K.M. HavsTAD. 2000. Indicators of Great Basin rangeland health. Journal of Arid Environments 45:289-304.

Dickey, J., M. Hall, M. Madison, J. Smesrud, M. Griswold, Q. CotTon, M. Heilmann, G. Roland, J. JorDaHL, R. Harasick, ET AL. 2005. Managing salt to stabilize the Owens Playa with saltgrass. Pages 147-150 in Proceedings of the International Salinity Forum, Riverside.

Drenovsky, R.E., AND J.H. Richards. 2005. Nitrogen addition increases fecundity in the desert shrub Sarcobatus vermiculatus. Oecologia 143:349-356.

FaCELLI, J.M., AND A.M. TEMbY. 2002. Multiple effects of shrubs on annual plant communities in arid lands of South Australia. Austral Ecology 27:422-432.

ForT, K.P., AND J.H. RichaRDS. 1998. Does seed dispersal limit initiation of primary succession in desert playas? American Journal of Botany 85:1722-1731.

Gage, E.A., AND D.J. Cooper. 2005. Patterns of willow seed dispersal, seed entrapment, and seedling establishment in a heavily browsed montane riparian ecosystem. Canadian Journal of Botany 83:678-687.

Garcia-Fayos, P., B. Garcia-Ventoso, and A. Cerda. 2000. Limitations to plant establishment on eroded 
slopes in southeastern Spain. Journal of Vegetation Science 11:77-86.

GUO, Q.F., AND J.H. BRown. 1997. Interactions between winter and summer annuals in the Chihuahuan Desert. Oecologia 111:123-128.

Harper, J.L. 1977. Population biology of plants. Academic Press, New York, NY

Harris, M.R., AND J.M. FACELLI. 2003. Competition and resource availability in an annual plant community dominated by an invasive species, Carrichtera аппиа (L. Aschers.), in South Australia. Plant Ecology 167:19-29.

Houle, G. 1996. Environmental filters and seedling recruitment on a coastal dune in subarctic Quebec (Canada). Canadian Journal of Botany 74:1507-1513.

Humphrey, L.D., AND E.W. SChupp. 1999. Temporal patterns of seedling emergence and early survival of Great Basin perennial plant species. Great Basin Naturalist 59:35-49.

James, J.J., Z.T. Aanderud, and J.H. Richards. 2006. Seasonal timing of $\mathrm{N}$ pulses influences $\mathrm{N}$ capture in a saltbush scrub community. Journal of Arid Environments 67:688-700.

JoHnson, C.K., AND N.E. West. 1988. Laboratory comparisons of 5 seed-trap designs for dry, windy environments. Canadian Journal of Botany 66:346-348.

Johnson, E.A., AND G.I. Fryer. 1992. Physical characterization of seed microsites: movement on the ground. Journal of Ecology 80:823-836.

Kent, M., AND P. COKER. 1992. Vegetation description and analysis: a practical approach. John Wiley \& Sons, Chichester, United Kingdom.

KujJPeR, D.P.J., D.J. Nijhoff, and J.P. BaKKer. 2004. Herbivory and competition slow down invasion of a tal grass along a productivity gradient. Oecologia 141:452-459.

Mandak, B., AND P. Pysek. 2001. Fruit dispersal and seed banks in Atriplex sagittata: the role of heterocarpy. Journal of Ecology 89:159-165.

ManNing, S. 2003. Owens Valley precipitation. Inyo County Water Department, Inyo County, CA.

McCune, B., AND J.B. Grace. 2002. Analysis of ecological communities. MjM Software Design, Gleneden Beach, OR

McLendon, T., and E.F. Redente. 1991. Nitrogen and phosphorus effects on secondary succession dynamics on a semi-arid sagebrush site. Ecology 72:2016-2024.

MiaO, S.L., R.E. Borer, and F.H. SkLar. 1997. Sawgrass seedling responses to transplanting and nutrient additions. Restoration Ecology 5:162-168

MotT, J.J., AND A.J. McComb. 1974. Patterns in annual vegetation and soil microrelief in an arid region of western Australia. Journal of Ecology 62:115-126.

. 1975. Effects of moisture stress on growth and reproduction of three annual species from an arid region of Western Australia. Journal of Ecology 63:825-828.

Mun, H.T., AND W.G. Whitford. 1989. Effects of nitrogen amendment on annual plants in the Chihuahuan Desert. Plant and Soil 120:225-231.

Nathan, R., AND H.D. Muller-Landau. 2000. Spatial patterns of seed dispersal, their determinants and consequences for recruitment. Tree 15:278-285.
NeaL, J.T., and W.S. MotTs. 1967. Recent geomorphic changes in playas of western United States. Journal of Geology 75:511-524.

Neter, J., M.H. Kutner, C.J. Nachtsheim, and W. Wasserman. 1996. Applied linear statistical models. 4th edition. McGraw-Hill, Boston.

Ono, D., S. Weaver, and K. Richmond. 2000. Quantifying particulate matter emissions from wind-blown dust using real-time sand flux measurements. Great Basin Unified Air Pollution Control District, Bishop, CA.

Richardson, S.J., R.B. Allen, D. Whitehead, F.E. CarSwell, W.A. Ruscoe, and K.A. Platt. 2005. Climate and net carbon availability determine temporal patterns of seed production by Nothofagus. Ecology 86:972-981.

SAS InSTITUTE, InC. 2001. SAS/STAT user's guide. Version 8. SAS Institute, Inc., Cary, NC.

SAUDER, R.A. 1994. The lost frontier: water diversion in the growth and destruction of Owens Valley agriculture. University of Arizona Press, Tucson.

Schupp, E.W., AND M. Fuentes. 1995. Spatial patterns of seed dispersal and the unification of plant-population ecology. Ecoscience 2:267-275.

Shumway, S.W. 2000. Facilitative effects of a sand dune shrub on species growing beneath the shrub canopy. Oecologia 124:138-148.

Stanton, M.L., AND D.A. Thiede. 2005. Statistical convenience vs. biological insight: consequences of data transformation for the analysis of fitness variation in heterogeneous environments. New Phytologist 166:319-337.

UNGAR, I.A. 1996. Effect of salinity on seed germination, growth, and ion accumulation of Atriplex patula (Chenopodiaceae). American Journal of Botany 83:604-607.

URBANSKA, K.M. 1997. Restoration ecology research above the timberline: colonization of safety islands on a machine-graded alpine ski run. Biodiversity and Conservation 6:1655-1670.

Urbanska, K.M., and M. Fattorini. 2000. Seed rain in high-altitude restoration plots in Switzerland. Restoration Ecology 8:74-79.

Weiner, J., S. Martinez, H. Muller-Scharer, P. Stoll, AND B. SCHMID. 1997. How important are environmental maternal effects in plants? A study with Centaurea maculosa. Journal of Ecology 85:133-142.

Wertis, B.A., AND I.A. UnGar. 1986. Seed demography and seedling survival in a population of Atriplex triangularis Willd. American Midland Naturalist 116:152-162.

Whitford, W.G., D.J. RAPport, and A.G. DE SoYZa. 1999. Using resistance and resilience measurements for 'fitness' tests in ecosystem health. Journal of Environmental Management 57:21-29.

Wood, D.M., AND W.F. Morris. 1990. Ecological constraints to seedling establishment on the pumice plains, Mount St. Helens, Washington. American Journal of Botany 77:1411-1418.

Received 8 December 2008 Accepted 23 September 2009 